\title{
The EU Lisbon Treaty and EU Development Cooperation: Considerations for a Revised EU Strategy on Development Cooperation in Eritrea*
}

\author{
By Daniel R. Mekonnen, Galway** and Mirjam van Reisen, Tilburg***
}

\section{A. Introduction}

The European Union (EU) is a leading global actor in development cooperation, in charge of the coordination of the programmes of its $27 \mathrm{EU}$ member states as well as providing direct financial support to developing countries. ${ }^{1}$ The EU development programme is subject to a dense and voluminous legal normative structure ${ }^{2}$ and the legitimacy of its actions are, more than is the case in sovereign states, rooted in the legal structure provided by its founding treaties and other supplementary instruments. ${ }^{3}$

This paper aims to identify the scope of legality of support under the new legal framework, with a particular discussion on development cooperation between the EU and Eritrea. EUEritrea diplomacy, trade and development cooperation are governed by essential treaty obligations. EU development cooperation in Eritrea is to be directed, among other things, by respect for human rights and democratic accountability, which are all severely lacking in Eritrea. In the 10th EDF, which covers the years 2009 to 2013, the EU has allocated $€ 122$

* This article is a revised version of a discussion paper presented at the European Parliamentary Hearing on "Eritrea: Refugees, Child Soldiers and European Policy," 29 November 2010, Brussels.

** Daniel R. Mekonnen at the time of writing was a Bank of Ireland Fellow at the Irish Centre for Human Rights, National University of Ireland, Galway; E-mail: danielrezene@gmail.com.

*** Mirjam van Reisen, Professor of International Social Responsibility, Endowed Chair Marga Klompé, Tilburg University, Department of Culture Studies, and Director of Europe External Policy Advisors (EEPA); E-mail: M.vanReisen@uvt.nl; mvreisen@eepa.be.

1 OECD, EU Development Cooperation: Improving but still Cumbersome, Press Release, 24 April 2012, available at: http://www.oecd.org/document/39/0,3746,en_21571361_44315115_50170663 _1_1_1_1,00.html (accessed 2 May 2012.).

2 Philipp Dann, Programme- und Prozesssteuerung im europäischen Entwicklungsverwaltungsrecht, EuR - Beiheft 2 (2008), pp. 108- 138.

3 Mirjam van Reisen \& Daniel R. Mekonnen, EU Development Cooperation: The Contours of Engagement at the Global and National Levels, in: Paul Gready / Wouter Vandenhole (eds.), Towards a Theory of Change: Human Rights and Development in the New Millennium, London, 2013, forthcoming. A number of arguments we make in the current contribution are further elaborated in the work cited herewith. It is the authors' hope that the re-exposition of these arguments in the current publication will provide a wider platform for the dissemination and discussion of these ideas. 
million in development aid to Eritrea. ${ }^{4}$ Under the previous EDF (2002-2007), Eritrea received $€ 113$ million from the EU. ${ }^{5}$

This article examines whether EU cooperation with Eritrea appears to be in contravention with EU treaty obligations to promote human rights, respect for the rule of law and democratic accountability. It is contended that EU's support to the Government of Eritrea, provided despite publicly available overwhelming evidence of human rights violations, lack respect to the rule of law and absence of democratic institutions, is a violation of the EU's own legal commitments. Moreover, given that support is provided in agreement with, and aimed to directly support, the Government of Eritrea, the EU could be regarded as condoning the violations of international law by the Government of Eritrea and as complicit with its human rights violations. The relevance of the question is examined in the context of a range of measures taken by the UN Security Council in relation to Eritrea, demonstrating a continuous concern with legal and political developments in Eritrea. The measures include two sets of sanctions adopted by Resolution 1907 of 2009 and Resolution 2023 of 2011 . Resolution 1907 imposes, among other things, a two-way arms embargo (import and export), including targeted sanctions against the political and military leadership in Eritrea. The targeted sanctions include travel ban and asset freeze against individuals and entities to be designated by a Security Council Committee. The subsequent Resolution 2023 expanded the restrictive measures with specific reference to the area of additional and complementary taxation of the Eritrean diaspora, the Eritrean mining sector and major financial services, three sources of income that facilitate the Eritrean regime's practices condemned by the Security Council. Especially the latter aspect of financing of the regime is of direct relevance to the question of EU funding. The Security Council is clearly intended to block income streams to the current regime and the EU aid programme seems to contravene this intention.

In order to justify the claim that the EU is in contravention with the intention of Security Council Resolutions 1907 and 2023 it is necessary to substantiate that the aid of the EU is in fact direct support to the Eritrean Government. We argue that when the EU approved, at least, the last package of development aid to Eritrea, it was well aware of the prevailing politicolegal crisis in Eritrea. Since then things have deteriorated irreparably. The fact that funds are given to the Eritrean Government in the form of direct bilateral aid, the EU may shoulder direct responsibility for what is done by the Eritrean Government in the context of projects implemented via EU development aid. It is this argument that will be the central element developed in this article. If the claim can be substantiated that EU aid is in fact facilitating the

4 Eritrea-European Community Country Strategy Paper and National Indicative Programme, for the Period 2009-2013, signed on 2 September 2009 (hereinafter "CSP for Eritrea," available at http://ec .europa.eu/development/icenter/repository/scanned_er_csp10NEW_en.pdf (accessed 25 November 2010); Country Profile on Eritrea, available at http://ec.europa.eu/europeaid/where/acp/country-coop eration/eritrea/eritrea_en.htm (accessed 1 May 2012).

5 Eritrea-European Community Country Strategy Paper and National Indicative Programme, for the Period 2002-2007, available at http://ec.europa.eu/development/icenter/repository/scanned_er_csp_ en.pdf (accessed 9 July 2012); Country Profile on Eritrea, note 4. 
actions of the Eritrean Government, it raises the question as to whether the EU is contravening its own commitments as defined by its legal framework for cooperation with third countries.

This article will discuss the legal framework of the EU in its cooperation with third countries as well as the specific framework with Eritrea. In order to assess the legality of the EU programme with Eritrea, the situation of Eritrean governance will be discussed in order to establish whether it can be conceived that EU aid in this country is guided by the essential principles of its cooperation with third countries.

\section{B. The Legal Framework for EU Cooperation with Third Countries}

The competence for EU development cooperation has been realised in the Treaty of Rome, and leading up to the signing of the Treaty, the French proposal to establish a European Development Fund (EDF) was a breaking point for negotiations on the signing of the first European Economic Community (EEC) Treaty. The French proposal was resisted by Germany and the Netherlands, but both countries agreed finally to the establishment of the fund as part of an agreement on the signing of an overall EEC Treaty. ${ }^{6}$ Therefore cooperation with developing countries is part of the original lay-out of the Union and its acquis communautaire.

The EDF was established for cooperation with colonies under the treaty at first, but then, with the fast evolving independence of former colonies, a new series of agreements arranged the mutual relationship of cooperation between these new independent states and the EU. The agreement would evolve from the Yaoundé and Lomé Agreements to the Cotonou Agreement $^{7}$ (2000) and form the basis of the EU acquis communautaire on development cooperation. These agreements relate to the countries from Africa, Pacific and Caribbean (ACP Group of countries), the historic partner countries of the EU member states. In the 1970 s the competence was expanded to include new regions, especially following the enlargement of the EEC with the UK and Ireland and in the 1980 s further, after the Iberian enlargement. A cooperation policy geared towards the specific dimension of "neighbourhood" followed the Eastward expansion in the new millennium. After the most recent enlargement of the EU, the framework for EU development cooperation has been further updated in recent times, particularly via its Development Cooperation Instrument (DCI), established in 2007. ${ }^{8}$ The signing of the EU Lisbon Treaty has created finalisation on the framework as it has evolved since the $1950 \mathrm{~s}$.

6 Mirjam van Reisen, Window of Opportunity, EU Development Cooperation after the fall of the Berlin Wall, New Jersey 2009.

7 Partnership Agreement between the Members of the African, Caribbean and Pacific Group of States on the One Part, and the European Community and its Member States, on the Other Part, signed in Cotonou, Benin on 23 June 2000, revised in Luxemburg on 25 June 2005, available at: http://www.a cpsec.org/en/conventions/cotonou/accord1.htm (accessed 25 November 2010).

8 For a detailed description of the history of the DCI legislation, see generally Sandra Bartelt, The Legislative Architecture of EU External Assistance and Development Cooperation, EuR - Beiheft 2 (2008), pp. 10-36. 
Article 208 of the Treaty on the Functioning of the European Union (TFEU or the Treaty of Lisbon $)^{9}$ provides that developing countries can benefit from financial support aimed at the eradication of poverty. Article 208 obliges the EU to design its development cooperation "within the framework of the principles and objectives" of its external action. The EU's principles and objectives of external action are defined in Article 21(1) of the Treaty of the European Union ${ }^{10}$ as follows:

The Union's action on the international scene shall be guided by the principles which have inspired its own creation, development and enlargement, and which it seeks to advance in the wider world: democracy, the rule of law, the universality and indivisibility of human rights and fundamental freedoms, respect for human dignity, the principles of equality and solidarity, and respect for the principles of the United Nations Charter and international law.

The obligation to respect the principles of the UN Charter and international law is repeated in Article 3(5) of the Treaty of the European Union. This is preceded by the cardinal principles in Article 2 of the same Treaty, which define the founding values of the EU as "respect for human dignity, freedom, democracy, equality, the rule of law and respect for human rights". Article 208 of the Treaty of Lisbon stipulates the main aim of EU development cooperation to be the "eradication of poverty."

On the other hand, there is also the DCI which governs EU's development agenda with a specific focus and application to countries in Asia and Latin America (or the non-neighbourhood and non-ACP-countries). The neighbourhood countries and the ACP countries can access particular budget lines under the DCI, and as such the DCI relates to all developing countries, providing financial support for thematic policy areas with resources provided through the General Budget of the EU. ACP countries have access to funding provided under the DCI in thematic areas. The ACP Sugar Protocol (which is particularly relevant to a number of ACP countries and a response to the negotiations on trade in Economic Partnership Agreements) is also included under the DCI Regulation. The DCI thematic budget lines are especially relevant for non-state actors. The DCI relates in a thematic sense to all developing countries and governs the resources from the general budget with developing countries; it therefore provides together with the Cotonou Agreement and the European Neighbourhood Policy (ENP) the sub-treaty legal framework of the EU's policy with developing countries.

9 European Union, Consolidated Version of the Treaty on the Functioning of the European Union, Official Journal of the European Union, 9 May 2008 (C 115/47), available at: http://eur-lex.europa. eu/LexUriServ/LexUriServ.do?uri=OJ:C:2008:115:0047:0199:EN:PDF (accessed 25 November 2010).

10 European Union, Consolidated Version of the Treaty of the European Union, Official Journal of the European Union, 9 May 2008 (C 115/13), available at http://eur-lex.europa.eu/LexUriServ/Lex Uri Serv.do?uri=OJ:C: 2008:115:0047:0199:EN:PDF (accessed 25 November 2010). 
The legally binding EU Regulation on the establishment of the $\mathrm{DCI}^{11}$ refers to respect for human rights, fundamental freedoms and democratic principles (preamble 6) as fundamental to the achievement of the objectives of development cooperation:

A political environment which guarantees peace and stability, respect for human rights, fundamental freedoms, democratic principles, the rule of law, good governance and gender equality is fundamental to long-term development.

Preamble 11 of the EU Regulation on DCI further identifies these as essential elements on which partnership and cooperation agreements are based.

The Community and its Member States have concluded partnership and cooperation agreements with some of these partner countries and regions aimed at making a significant contribution to the long-term development of the partner countries and the wellbeing of their people. The essential elements on which these partnership and cooperation agreements are based are the common and universal values of respect for, and promotion of, human rights, fundamental freedoms, democratic principles and the rule of law.

We understand that at this moment, there are no EU projects funded under the DCI in Eritrea. However, as one of the most major development instruments of the EU, we believe that the legal framework provided by the DCI is also a very important reference point in highlighting human rights as an essential clause of development cooperation. ${ }^{12}$ As the EU budget-related

11 European Parliament and European Council, Regulation (EC) No 1905/2006 of the European Parliament and of the Council of 18 December 2006 Establishing a Financing Instrument for Development Cooperation, Official Journal of the European Union, L 378/41, 27.12.2006. Dann, note 2, makes the point that the regulatory framework on development of the EU is dense and voluminous in comparison to Member States or other donors.

12 For further exposition on the applicability of the DCI and the Cotonou Agreement, we refer the reader to the analysis developed by Bartelt, note 8 . According to the established practice of the EU, Bartelt opines, when an overlap exists between two or more development instruments, the tension is resolved by the principle of subsidiarity, which is explained as follows. This principle, which is based on article 11 of the DCI, provides that specific thematic programmes of the DCI are implementable only in cases where EU policy objectives cannot be achieved through country or regional programmes (such as, for example, through the Cotonou Agreement) and when the programme is implemented by or through an intermediary organisation. This means that thematic programmes are "subsidiary to geographic programmes, the latter being the preferred instrument for cooperation." Therefore, "thematic programmes are ... meant to supplement geographic cooperation where better results can be achieved at a thematic level." Based on the above observation, since EU-Eritrea development objectives are best served by the Cotonou Agreement, the DCI may not be applicable in Eritrea at this particular moment. In our case, the Cotonou Agreement appears to be the most important instrument governing EU-Eritrea development cooperation. In support of her argument, Bartelt further cites Commission Communication, External Actions through Thematic Programmes under the Future Financial Perspectives 2007-2013, COM (2005) 324 final, p. 3; Para 53 of the European Consensus on Development which says: "In this framework, the thematic programmes are subsidiary, complimentary and defined on the basis of their distinctive value added vis-à-vis the geographical pro- 
development instrument, the DCI translates the intentions of the legislator in a sub-treaty legal instrument. Earlier in 2000, the Cotonou Agreement, which governs the bilateral and regional relations of the EU with ACP countries through the EDF, identified essential elements for cooperation: respect for human rights, democracy and good governance. The overall purpose and scope of the Cotonou Agreement is defined in article 1 as to "consolidate and support democracy, the rule of law, human rights and fundamental freedoms, good governance, gender equality and related instruments of international law." One of the guiding principles of the Cotonou Agreement is article 9(1):

Cooperation shall be directed towards sustainable development centred on the human person, who is the main protagonist and beneficiary of development; this entails respect for and promotion of all human rights.

Respect for all human rights and fundamental freedoms, including respect for fundamental social rights, democracy based on the rule of law and transparent and accountable governance are an integral part of sustainable development.

In both the Treaty of Lisbon and the Cotonou Agreement respect for human rights, the rule of law and democratic accountability are among the fundamental principles that should underpin ACP-EU cooperation. As one of the 79 ACP countries, Eritrea is currently a beneficiary under the EDF. The Cotonou Agreement provides for mechanisms by which the ACP-EU commitment to development cooperation can be evaluated on the basis of regular political dialogue, as stipulated in article 8(4) of the same agreement. One of the mechanisms stipulated by this article is the "regular assessment of the developments concerning the respect for human rights, democratic principles, the rule of law and good governance." Article 8(2) of the Cotonou Agreement states that the objective of political dialogue is to prevent recourse by one of the parties to the non-execution clause; by implication, this means that if one party is not satisfied with the performance of the other, that party has recourse to the non-execution clause. This possibility is also clearly stipulated in article 96 of the Cotonou Agreement and the first three articles in Annex VII of the same agreement. Currently the ACP has set up a working group on the Future Perspectives of the ACP, to reflect on its future after 2020 when the Cotonou Agreement expires. ${ }^{13}$ However, as will be seen later and as also noted by Kirsten Schmalenbach, there is a quite common fate of all dispute settlement mechanisms of development organizations. They are all known for being "paper tigers." 14

EU law contains binding provisions in relation to all aspects of its external relations, which guide the scope and extent of its foreign policy instruments. Given that the EU's existence is

grammes." European Union, European Consensus on Development, Official Journal of the European Union, 2006/C 46/01, 24 February 2006, available at: http://ec.europa.eu/development/icenter/repo sitory/european_consensus_2005_en.pdf (accessed 25 November 2010).

13 Dietmar Nickel, Was kommt nach Cotonou? Die Zukunft der Zusammenarbeit zwischen der EU und den Afrika-, Karibik- und Pazifikstaaten, SWP-Studie, S 13, Juni 2012.

14 Kirsten Schmalenbach, Accountability: Who is Judging the European Development Cooperation?, EuR - Beiheft 2 (2008), pp. 82-83. 
based on a legal agreement between the EU Member States, the legal framework of the EU is particularly important. The Lisbon Treaty has strengthened the competence of the EU in external relations by increasing the scope of its competence in diplomacy. The framework of EU development cooperation creates a binding set of parameters, the provisions of which have been tested by the European Court of Justice in a number of cases brought by the European Parliament to double-check the legality of certain activities proposed and implemented by the European Commission under the legal provision of development cooperation. ${ }^{15}$

\section{The EU Country Strategy Paper for Eritrea (2009-2013)}

A Country Strategy Paper (CSP) is the agreement of a policy of cooperation between the EU and a third country. The CSP describing cooperation between the EU and Eritrea is approved by the governments on the two sides: the Government of Eritrea and the EU Member States through a Member States Committee. Linked to the CSP is the budget described in the National Indicative Programme (NIP). ${ }^{16}$ The 2009-2013 CSP was signed by the Head of Delegation for the European Union (Ms. Paola Amadei at the time) and the National Authorising Officer (NAO) for the Eritrean Government (Mr. Yemane Gebremeskel at the time). It was signed on 2 September 2009. As with other ACP countries, EU development cooperation with Eritrea is first and foremost governed by the Treaty of Lisbon and the Cotonou Agreement. This reality is recognised in the CSP for Eritrea, which states explicitly that the "[Lisbon] Treaty and the Cotonou Agreement provide the legal basis for [EU] cooperation with the ACP countries." 17 The Cotonou Agreement is a treaty to which the EU Member States and the ACP countries are party, and cooperation based on this treaty is essentially a government-to-government relationship. The budget authorisation for implementation is provided by the NAO in Eritrea, usually a member of the government or a government official charged with this responsibility. The CSP for Eritrea emphasises the eradication of poverty and sustainable economic development, among other things, as core elements of EU-Eritrea development cooperation. In addition to the founding treaties of the EU and the Cotonou Agreement, the European Consensus on Development is also recognised in the CSP for Eritrea as providing the general policy framework for EU development cooperation. The document envisages development cooperation in terms of Europe's core democratic values such as respect for human

15 European Court of Justice. Judgement of the Court (Grand Chamber). (Action for annulment - Commission decision approving a project relating to border security in the Philippines - Decision adopted on the basis of Regulation (EEC) No 443/92 - Commission's implementing powers - Limits. 23 October 2007; European Court of Justice Judgement of the Court (Grand Chamber) (Action for annulment - Article 47 EU - Common foreign and security policy - Decision 2004/833/CFSP Implementation of Joint Action 2002/589/CFSP - Combating the proliferation of small arms and light weapons - Community competence - Development cooperation policy) In Case C-91/05, 20 May 2008.

16 CSP for Eritrea, note 4.

17 CSP for Eritrea, note 4. 
rights, democracy, fundamental freedoms and the rule of law. ${ }^{18}$ The following are some of the sad realities boldly stated in the CSP for Eritrea. Since independence in 1991, Eritrea has been ruled without a constitution and its Government has never published a national budget. The country had a transitional National Assembly, but this supreme national deliberative body has not been convened since 2002. The CSP also describes Eritrea as an "administratively and fiscally centralised" state. ${ }^{19}$ There is also a total absence of independent civil society organisations in Eritrea. The CSP for Eritrea clearly states that civil society organisations in the country, such as the National Union of Eritrean Women, are affiliated with the ruling party. Although the CSP does not explicitly say, it alludes to the fact that there are currently no independent civil society organisations in Eritrea. What are currently present in Eritrea are GONGOs (government-operated NGOs), set up or maintained by undemocratic governments as "independent organisations" to disguise foreign aid and pay lip service to civil society participation. ${ }^{20}$

By 2008, one year before the signing of the CSP for 2009-2013, the Government of Eritrea had been accused by internationally reputed organisations of severe and systematic human rights violations and of lacking democratic institutions. Reporters Without Borders, for example, ranked Eritrea in 2008 in the last position of its annual ranking of press freedom "for the simple reason that the situation has gone from bad to worse." ${ }^{21}$ In 2009 Human Rights Watch called Eritrea a "giant prison" demanding "service for life" 22 of its citizens, pointing to a range of problems including the absolute lack of any form of press freedom, the suppression of independent civil society organisations, the indefinite military conscription, the exodus of refugees - despite the extreme difficulty to obtain exit visas and a shoot-to-kill policy at the border. In 2008, Amnesty International had asked attention for the banning of faiths since 2002 , and arrest of believers, the frequent arrest of journalists and political prisoners, indefinite military conscription and practices of torture and ill treatment. ${ }^{23}$ In 2009, the Oslo Centre for Peace and Human Rights sponsored the publication of a detailed report by Kjetil Tronvoll on the alarming level of human rights violations in Eritrea. This report, which is prefaced by the former Norwegian Prime Minister, Kjell Magne Bondevik, describes how extensive and systematic the political oppression and human rights violations in the country are. ${ }^{24}$

18 European Consensus on Development, note 8.

19 CSP for Eritrea, note 4, p. 7.

20 Daniel R. Mekonnen, The Abolition of Female Circumcision in Eritrea: Inadequacies of New Legislation, African Human Rights Law Journal 7(2) (2007), p. 408.

21 Reporters Without Boarders, Eritrea, available at http://en.rsf.org/eritrea-eritrea-07-02-2008,25386 (accessed 9 July 2012).

22 Human Rights Watch, Service for Life: State Repression and Indefinite Conscription in Eritrea, Washington 2009.

23 Amnesty International, 2008 Report, available at http://www.amnesty.org/en/region/eritrea/report-2 008 (accessed 9 July 2012).

24 Kjell Magne Bondevik, Preface, in: Kjetil Tronvoll, The Lasting Struggle for Freedom in Eritrea: Human Rights and Political Development, 1991-2009, Oslo 2009, p. 9. 
By 2008, it was well known that President Isaias Afewerki had been in power of a transitional government since 1993, and that there was no independent judiciary, no functioning parliament, and no working constitution in the country. The Eritrean Government has never published its national budget officially, and there is no independent budget authority or any independent budget control mechanism in the country. ${ }^{25}$ There is no clear demarcation of military and government structures and the educational system is under military control. There is therefore no separation of powers and the country lacks any basic formation of democratic governance. In its 2008 annual report, the US State Department noted the "abridgement of citizens' right to change their government through a democratic process." ${ }^{26}$ By end of 2008 , Eritrea produced 62700 new asylum seekers around the world. The simplest arithmetic model translates this into 5225 refugees per month. In this regard, Eritrea was preceded only by Zimbabwe which had 118500 new claims in 2008. Even failed or chaotic states, such as Somalia and Iraq, which have greater population numbers than Eritrea, were preceded by Eritrea in relation to refugee outflow. ${ }^{27}$

In addition to its internal political problems, Eritrea has also been implicated as a threat to regional peace and security in the Horn of Africa well before the approval of the latest EU development aid in 2009. This has been especially well document by the UN Monitoring Group on Somalia (and since 2010 on Somalia and Eritrea). For instance, prior to 2009, when the EU signed a CSP with Eritrea, the UN Monitoring Group identified Eritrea as a principal violator of the arms embargo to Somalia, and observed that "Eritrea continues to provide political, financial and military support to armed opposition groups" in Somalia and claimed substantial military and financial support was provided to opposition groups in Somalia. ${ }^{28}$ The Monitoring Group stated it's believe that "Eritrean arms embargo violations take place with the knowledge and authorization of senior officials within the Eritrean Government and the ruling People's Front for Democracy and Justice (PFDJ)." ${ }^{29}$ Pursuant to this report, UN Security Council Resolution 1907 was adopted - still prior to the adoption of the CSP by the EU and Eritrea. The CSP failed to make reference to the allegations of Eritrean support to armed groups in Somalia which are designated as "terrorists." Some shortcomings of the Eritrean Government are described in the CSP for Eritrea. However, the CSP for Eritrea does not assess whether or not the reality in Eritrea constitutes a favourable legal and political environment for respect of the principles set out in the Treaty of Lisbon or the progressive realisation of the objectives of development cooperation. The CSP also does not address how

25 Daniel R. Mekonnen, Eritrea: Held Hostage by Its Own Government, in: Social Watch Annual Report, Montevideo 2010, p. 101.

26 US Department of State, Country Reports on Human Rights Practices, available http://www.state.g ov/j/drl/rls/hrrpt/2008/af/119000.htm (accessed 9 July 2012).

27 UNHCR, Global Trends: Refugees, Asylum Seekers, Returnees, Internally Displaced and Stateless Persons, Geneva 2009, p. 16.

28 Report of the Monitoring Group on Somalia pursuant to Security Council resolution 1811 (2008), 10 December 2008, p. 26.

29 Report of the Monitoring Group, note 28, p. 26. 
development cooperation will contribute to the eradication of poverty in a country where people living in poverty have no recourse to a judicial or political system capable of responding to their complaints. The lack of verification in the CSP of whether the conditions in Eritrea allow for the implementation of EU treaty principles and objectives constitutes a major omission. It raises the question of whether or not, and if so how, the European Commission has satisfied itself of the ability of the Government of Eritrea to respect the key principles and objectives of development cooperation. The above analysis suggests that ample evidence was available when the CSP was signed that Eritrea has a serious human rights problem, lacking any democratic institutions and violating all basic principles of good governance. It is also identified that sources were credible and manifold. These sources were also fully available to the European Commission, the EU institutions and the EU Member States. Notwithstanding the availability of this information, the EU chose to sign a cooperation agreement with Eritrea.

\section{Review of the Period 2009-2012}

In a report published in September 2010, the International Crisis Group (ICG), one of the leading global think tanks on human security, described Eritrea as a country on the brink of becoming another failed state in the Horn of Africa. In a region that has already produced one failed state in the last 20 years, the possibility of Eritrea becoming another failed state is not far-fetched. ICG's warning is apparent in the following paragraph:

All this is necessary to prevent another failed state from emerging in the Horn [of Africa]. That outcome is otherwise distinctly possible given the widespread lack of support for the government within the country and the deteriorating state of the army, whose ability to either sustain Isaias Afwerki's regime or to successfully manage regime transition is increasingly questionable. ${ }^{30}$

In addition to the accounts we provided in the preceding paragraphs, the issue of child soldiers, forced labour and mass exodus of the young generation are some of the most pressing challenges in Eritrea. ${ }^{31}$ A report leaked from the Office of the State President in February 2009 revealed shocking figures of underage military conscription in Eritrea. According to this report, in 2007, the Eritrean Government forcefully enlisted 3510 underage conscripts, made up of 1911 male underage conscripts and 1599 female underage conscripts. ${ }^{32}$ These children

30 ICG, Eritrea: The Siege State, Africa Report No. 163, 21 September 2010, p. ii.

31 The discussion on this issue draws on Daniel R. Mekonnen, Transitional Justice Implications of the Use of Child Soldiers in Eritrea, in: Stephan Parmentier et al (eds.), Rehabilitation and Reintegration of War-Affected Children, Antwerp 2012, pp. 263-281.

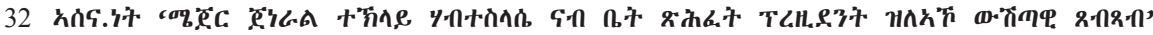
(Asena.net, Internal Report of Major-General Teklay Habteselassie to the Office of the President'), available at http://asena.delina.org/images/presidentteklay.pdf (accessed 4 February 2009). This is a leaked report sent from the commander of the Sawa Training Camp to the state President, Isaias Afwerki. The report illustrates that, as compared to previous rounds, the majority 
were enlisted in the twenty-first round of the national military service programme (NMSP), which takes place approximately every six months in the Sawa Military Training Centre. Although this report cannot be taken as conclusive, the information would appear to corroborate the widespread understanding that children are being recruited for military service forcefully. As regards the twenty-second round of the NMSP, which concluded in June 2009, official government sources indicate that the majority of participants in this round were born in the post-independence era, which would mean that all such recruits were underage children at the time of conscription. Forty per cent of the trainees in this particular round were female conscripts. ${ }^{33}$ Witnesses report that in several instances girls have been obliged to perform sexual services for military commanders; if they become pregnant, these girls are dispelled from military service with no option but to undertake the dangerous journey to leave the country illegally without any means of support. ${ }^{34}$

In addition to growing concerns about underage military conscription, there is a widespread practice of forced labour in Eritrea, posing additional challenges for human rights and democratisation efforts in the country. ${ }^{35}$ The allegation of the widespread use of forced labour for public projects is linked to the absence of a working population due to the practice of indefinite military conscription. A reasonable concern, therefore, is whether or not forced labour is involved in the implementation of EU development programmes in Eritrea. Given the possibility that children are recruited by the military, this concern extends to the potential implementation of EU development programmes by children through forced labour. Due to alarming levels of political repression, economic meltdown and excessive militarism, Eritrea has also become one of the leading refugee-producing countries in the world. Despite its small population of around 4 million (out of which around 1.5 million are said to be outside of the country), Eritrea's alarming record of human rights violations has caused it to be ranked as the second largest source of refugees in the world (in absolute numbers). ${ }^{36}$ In a society which is fleeing the country in such unprecedented scales, it is difficult to imagine the ultimate beneficiaries of development cooperation, which in the normal course of things should be a population disengaged from mass exodus. There is a failure on the part of the EU to acknowledge this sad situation in Eritrea, creating an undue burden on the people who have had to flee

of conscripts in the twenty-first round were very young. This is particularly mentioned on page 4 of the report. The English translation of the report is available at: http://www.arkokabay.com/news/in dex.php?option $=$ com_content $\&$ view $=$ article $\&$ id $=254$ :translation-of-the-report-of-the-commanderof-the-sawa-military-training-camp-to-the-office-of-the-eritrean-president\&catid=46:documents\&I temid $=101$ (accessed 25 November 2010).

33 This is according to a speech by the Eritrean President given at the graduation ceremony of the twentysecond round of the NMSP. See: Shabait.com News, Participants of 22nd Round National Service Graduate, 28 June 2009.

34 Cecilia M. Bailliet, Examining Sexual Violence in the Military within the Context of Eritrean Asylum Claims Presented in Norway, International Journal of Refugee Law 19 (2007), p. 471-510.

35 On the pervasiveness of forced labour in Eritrea, see generally Gaim Kibreab, Forced Labour in Eritrea, Journal of Modern African Studies, 47(1) (2009), p. 41-72.

36 UNHCR, note 27, p. 16. 
Eritrea. In some cases, the EU member states' policies have resulted in Eritrean refugees being refused asylum and sent back to countries who have poor records on refugee protection. In several instances, Eritrean asylum seekers have also been deported from some European countries to Eritrea. In a landmark case of Hirsi Jamaa and Others v Italy, the European Court of Human Rights ruled that Italy returned African migrants who were fleeing on a boat without checking the danger of this decision to their life. As a result, Italy was ordered to pay financial compensation for damages to each of the migrants. ${ }^{37}$

As we noted earlier, when approving the last package of development aid to Eritrea, covering the period 2009-2013, the EU was well aware of the prevailing politico-legal crisis in Eritrea. In this regard, we would like to quote some extraordinary testimony given by $\mathrm{Mr}$. Louis Michel about the deteriorating political situation in Eritrea. ${ }^{38} \mathrm{Mr}$. Michell was the most senior official of the EU in charge of development cooperation during the time when the last two packages of development aid to Eritrea were approved by the EU. He was the EU Commissioner for Development Cooperation. As such, his testimony comes as one of the most revealing accounts for purposes of our paper. Before citing some words of Mr. Michel, we would like to briefly explain the genesis of his testimony. Mr. Michel was speaking at a European Parliament hearing initiated by a caucus of six EU Parliamentarians in conjunction with the Brussels-based NGO, Europe External Policy Advisers (EEPA). During his tenure as EU Commissioner for Development Cooperation, Mr. Michel was a staunch advocate of the last two packages of development aid that were given to the Eritrean Government during his tenure. At the European Parliamentary hearing, which took place in December 2009, he admitted that his former conviction about Eritrea was erroneous. This was evident from his comment in relation to the plight of Dawit Isaak, an Eritrean-Swedish journalist who remained in detention without trial since September 2001 and for his freedom Mr. Michel claims to have worked a lot (in the context of negotiations for development aid) but to no avail. $\mathrm{He}$ indicated that during his tenure as Commissioner for Development Cooperation he travelled to Eritrea five times, more than any other African country, with the hope of influencing the behaviour of Eritrean Government leaders. However, he was frankly genuine in admitting that his policy has proven counterproductive, because it neither ensured the release of political prisoners such as Dawit Isaak nor convinced Eritrean Government officials to open up political space. He added that instead of improving, the situation worsened every year. Between his first and last visit to Eritrea, he said, he saw no progress on the part of the Eritrean leadership

37 European Court of Human Rights, Hirsi Jamaa and others v. Italy, Application No. 27765/09, Judgment of 23 February 2012.

38 The account on Mr. Michel's testimony is based on a handwritten note taken by one of the current authors who was present at the parliamentary hearing. This account is also used in another forthcoming joint publication of the current authors. For a full report of the parliamentary hearing, see Daniel R. Mekonnen, An Afternoon with Louis Michel in the European Parliament, 11 December 2009, available at http://asmarino.com/news/435-an-afternoon-with-louis-michel-in-the-european-p arliament-. 
and to his dismay relations with the Eritrean President in particular became more difficult than they were three or four years earlier before he left his position at the EC.

Mr. Michel's parliamentary account was clearer in no other part than that which narrates his last trip to Eritrea, which took place in August 2009, shortly after the approval of the latest aid package. In that trip, Mr. Michel travelled to Asmara with guarantees given to him by the Eritrean Government of the release of Dawit Isaak, the Eritrea-Swedish journalist who remains in detention without trial for more than ten years. After his arrival in Asmara, Mr. Michel found that the government was not honouring its promise and Dawit Isaak was not to be released. According to Mr. Michel, this came as a very disappointing experience, and he felt offended by the actions of the Eritrean President, particularly by the empty promise given to him before he departed Brussels. When Mr. Michel made these personal observations, he was no longer a senior political figure of the EU. Understandably, he was at liberty to speak his mind freely, and we believe he did so without the strings of political correctness. Thefore, his confession comes as something of an extraordinary revelation. For Eritreans and their friends, it was their first time to hear Mr. Michel spoke candidly and in public on the real challenges in Eritrea. We believe his remarks are objective reflections of a person with an inside knowledge on how the situation has deteriorated in Eritrea.

Overall, there is lack of political and judicial institutional mechanisms in Eritrea to raise concerns about human rights violations in the country. The EU could be potentially condoning the perpetration of human rights violations in Eritrea. Its continued support to the Government of Eritrea could be interpreted as approving Eritrean Government's practices. The European Commission does not address in the CSP how it is ensuring that it does not contribute to or aggravate human rights violations in Eritrea. Moreover, the CSP does not give credible evidence that the support provided by the agreement with the Government of Eritrea can effectively contribute to the eradication of poverty. Therefore, there is a need to determine if EU development cooperation with Eritrea is contravening EU law.

\section{E. Respect for the UN Charter and International Law}

Another important benchmark to gauge EU development cooperation with Eritrea is the EU's commitment to respect for the principles of the UN Charter and international law, as stipulated in Articles 21(1) and 3(5) of the Treaty of the European Union. There is no more important reference point in this regard than UN Security Council Resolution 1907, which imposes stringent sanctions against Eritrea. Resolution 1907 has serious political implications in relation to the unrealistic stance of the EU with regard to its relations with Eritrea. Resolution 1907 is mainly an outcome of Eritrea's flawed diplomatic policy, an approach that is described by the ICG as one that favours war as a foreign policy and is notoriously known for its "alarming tendency of fight first and talk later." ${ }^{39}$ Most importantly, as a restrictive measure mandated by Chapter VII of the UN Charter, Resolution 1907 is a binding decision and a 
reflection of the inviolability of the principles of the UN Charter and concomitant international law, to which the EU has vowed its allegiance. At policy level, the EU has committed itself to implement the restrictive measures of Resolution 1907 by the Council of Europe Decision adopted on 1 March 2010. ${ }^{40}$ While this has an inevitable bearing on the position of the European Commission on Eritrea, the Commission is yet to clarify the impact of this on its development cooperation with Eritrea.

Resolution 1907 was adopted by the UN Security Council on two major grounds: (a) because of Eritrea's involvement in the Somalia Civil War in contravention of a number of UN Security Council resolutions and (b) because of Eritrea's failure to peacefully resolve a border conflict with Djibouti. As is well known, Eritrea's relations with its neighbouring counties have always been troubled. Since independence in 1991, Eritrea has clashed with four of its five immediate neighbours, namely Djibouti, Ethiopia, Sudan and Yemen. The only immediate neighbour with which Eritrea has not clashed is Saudi Arabia. Eritrea is currently involved in a proxy war with Ethiopia fought in Somalia, a country that does not even share a common border with Eritrea. ${ }^{41}$ As a result, Eritrea has amassed an "unrivalled record of international provocation", ${ }^{42}$ which finally led to the adoption by the UN Security Council of Resolution 1907 in December 2009. The measures adopted by Resolution 1907 include targeted financial sanctions, travel and aviation bans and an arms embargo against Eritrea and its military and political leadership. The level of indignation felt by the international community against the Eritrean Government is apparent from the antecedents of Resolution 1907. The Resolution was first initiated by IGAD and subsequently backed by the AU before it was finally endorsed by the UN Security Council. It is described as the first ever to be formally initiated by the AU against its own member state since the experience of apartheid in South Africa, thus becoming one of the most exceptional resolutions in the history of the UN. ${ }^{43}$

As previously described by one of the present authors, this sad development is a rude awakening to the EU's flawed foreign policy on Eritrea. ${ }^{44}$ This is particularly true as it came only three months after the EU approved development aid of $€ 122$ million to Eritrea, in dis-

40 Council of Europe, Council Decision 2010/127/CFSP, Concerning Restrictive Measures on Eritrea, Official Journal of the European Union, 1 March 2010. See also Council of Europe, Council Decision 2010/414/CFSP, Official Journal of the European Union, 26 July 2010, amending Council Decision 2010/127/CFSP.

41 On this issue, see generally Daniel R. Mekonnen \& Paulos Tesfagiorgis, The Causes and Consequences of the 1998-2000 Eritrean-Ethiopian Border Conflict: The Need For a Holistic Approach towards Transitional Justice, in: Roba Sharamo and Berouk Mesfin (eds.), Regional Security in the Post-Cold War Horn of Africa, Pretoria 2011, pp. 65-94.

42 Nathaniel Meyers, Africa's North Korea: Inside Eritrea's Open-Air Prison, Foreign Policy, July/ August 2010, available at http://www.foreignpolicy.com/articles/2010/06/21/africas_north_korea?p age $=0,0$ (accessed 5 April 2012).

43 Meyers, note 42, for example, writes: "It was the first time the African Union had ever supported sanctions against one of its own members.".

44 Mirjam van Reisen, A New Year, A New Treaty, but the same Old Problems?, European Voice, 14 January 2010. 
regard of continued warnings by concerned stakeholders such as Eritrean diaspora activists and human rights groups. Given the stringent sanctions of the UN against Eritrea, the EU may at some stage find itself contradicting the requirements of Articles 3(5) and 21(1) of the Treaty of the European Union. To avoid this, the EU needs to revise its policy and methodology in relation to development cooperation in Eritrea. As such, Eritrea provides a test case for the EU's external policy under its expanded competence provided under the Treaty of Lisbon, and of the capacity of the newly established European External Action Service to strengthen policy in this area.

\section{F. Irregularity and Procedural Means of Redress}

The fact that the Eritrean Government is a notorious violator of human rights is a well-established truth. According to different estimations, there are currently tens of thousands of victims of detention without trial and enforced disappearance in Eritrea. ${ }^{45}$ In addition to several credible sources we cite elsewhere in this work, there are at least four landmark decisions given by regional and international semi-judicial organs which further corroborate our claim. These are two judgements given by the African Commission on Human and People Rights (ACH$\mathrm{PR})^{46}$ and two other judgements given by the UN Working on Arbitrary Detection. ${ }^{47}$ In addition to these, there are also many other judgements or judicial findings by national jurisdictions which show that the Eritrean Government is a recidivist violator of human rights. ${ }^{48}$ In all of these judgements, the Eritrea Government was found to be in violation of its international obligations by causing, for example, the incommunicado detection of thousands of individuals for many years. In the case of judgements rendered by the ACHPR and UN Working Group on Arbitrary Detention, the government was specifically requested to rectify its recidivist behaviour by realising some victims of arbitrary detention or by bringing them to a court of law. Theses judgements involve mainly the plight of more than eleven highranking government officials and more than a dozen journalists who remained in detention without trial since September 2001. To this date, the government has never respected the judgements of the ACHPR and UN Working Group on Arbitrary Detention. These violations,

45 See, for example, Human Rights Watch, note 22, p. 19; and Tronvoll, note 24, p. 36.

46 Liesbeth Zegveld and Mussie Ephrem v The Government of Eritrea, ACHPR, Communication No 250/2002, 19th Activity Report of the ACHPR; Article 19v Eritrea, ACHPR, Communication No 275/2003, 22nd Activity Report of the ACHPR, Annex II.

47 Mahmoud Sherifo et al $v$ Eritrea, UN Working Group on Arbitrary Detention, UN Doc E/ CN4/2003/8/Add1, 54 (2002), 5 March 2002. See also UN Working Group on Arbitrary Detention, Opinion No 23/2007, adopted on 27 November 2007.

48 For a detailed discussion on this, see generally Daniel R. Mekonnen \& Loot Pretorius, Prosecuting the Main Perpetrators of International Crimes in Eritrea: Possibilities under International Law, Journal for Juridical Science, 33(2) (2008), pp. 76-108; Annie O’Reilly, Eritrea's National Service Program: The Human Rights - Human Trafficking Perspective, DePaul Journal of Rule Law, Fall 2010 , pp. 1-22; Simion M. Weldehaimanot, From Prisoners to Refugees: The Right to Leave and its Ramifications in Eritrea, East African Journal of Peace and Human Rights 17(1) (2011), pp. 230-261. 
added with other violations of the Eritrean Government do constitute crimes against humanity as are defined by the relevant provisions of international law. ${ }^{49}$ The violations are contrary to Eritrea's international obligations as defined by international human rights treaties it has ratified. ${ }^{50}$ This makes the Eritrean Government responsible for the human rights violations committed in the country in recent years.

Having established the culpability of the Eritrean government, it is now important to examine the level of accountability of the EU in the human rights violations that are currently taking place in Eritrea. This is very important in order to identify the most practical procedural means of redress. In this regard, we borrow some insightful guidance from Schmalenbach. ${ }^{51}$ In our case, since we are taking about grave human rights violations, the most important remedy appears to be judicial accountability, particularly that which is based on international criminal accountability. As to the criminal responsibility of the Eritrean Government and the remedy to that effect, we refer the reader to some previous works ${ }^{52}$ on this particular topic and leave the issue at this point, because our focus here is mainly on EU accountability, which may not fall strictly under the domain of criminal accountability. For the latter purpose, we understand that judicial accountability mechanisms may prove hardly to achieve. As noted by Schmalenbach judicial accountability measures against the EU require the establishment of a direct link between an alleged unlawful conduct of the EU and the ensuing violation, and this task is not very easy. ${ }^{53} \mathrm{Schmalenbach}$ further warns that "if it is possible that other determining factors intervened, particularly the beneficiary country's latitude, then the causality chain is easily disrupted." 54 In the case of Eritrea, the extremely unpredictable behaviour of

49 See, for example, O’Reilly, note 48, and Mekonnen \& Pretorius, note 48.

50 These include mainly but not only: the International Covenant on Civil and Political Rights (ICCPR); the International Covenant on Economic, Social and Cultural Rights (ICESCR), Convention on the Rights of the Child (CRC); and Convention on the Elimination of all Forms of Discrimination Against Women (CEDAW). At regional level, Eritrea has also ratified the African Charter on Human and Peoples' Rights (African Charter) and the African Charter on the Rights and Welfare of the Child (ACRWC).

51 Schmalenbach, note 14 , pp. 82-83.

52 In addition to the sources cited in note 48, we believe the following are some of the most important works on this particular topic: Simon M. Weldehaimanot, African Law of Coups and the Situation in Eritrea: A Test for the African Union's Commitment to Democracy, Journal of African Law 54(2) (2010), pp. 232-257; Petros B. Ogbazghi, Personal Rule in Africa: The Case of Eritrea, African Studies Quarterly 12(2) (2011), p. 1-25; Gerard Prunier, Eritrea and its Discontents, speech delivered at the Conference of the Association for the Study of the Middle East and Africa (ASMEA), 5 November 2010, available at www.vimeo.com/18716003 (accessed 10 December 2010); David O'Kane \& Tricia Redeker Hepner (eds.), Biopolitics, Militarism and Development: Eritrea in the Twenty-First Century, New York/Oxford 2009; Nicole Hirt, "Dreams Don't Come True in Eritrea": Anomie and Family Disintegration due to the Structural Militarization of Society, GIGA Working Papers, 119/2010, January 2010.

53 Schmalenbach, note 14, pp. 82-83.

54 Schmalenbach, note 14, p. 119. 
the Eritrean Government means that there are indeed numerous intervening factors that could disrupt the causality chain on the part of the EU.

The most that can be said about the misconduct of the EU is its failure to diligently exercise its functions of supervision and monitoring with regard to the huge of amount of funds that were sent to Eritrea. Understandably, this does not put the EU on the same level of culpability with that of the Eritrean Government which is actively and directly involved in the perpetration of grave human rights violations. In our case, we do not believe that the alleged misconduct of the EU can be described as something which involves direct or active participation in the perpetration of human rights violations in Eritrea. As such, we understand that it would be difficult to establish, at least at this particular moment, the required causational link to hold the EU civilly or criminally accountable for the human rights violations perpetrated in Eritrea. Sometimes judicial dispute settlement or accountability mechanisms of development organisations are generally described as "paper tigers," this being a quite common feature of such dispute resolution mechanisms, as underscored by Schmalenbach. ${ }^{55}$ There are however alternative accountability measures. In in this regard, Schmalenbach discusses a number of such options which include: financial scrutiny at the European Court of Auditors, democratic scrutiny at the European Parliament, political scrutiny at the Council and EU Member States, legal scrutiny at the European Court of Justice, and non-legal security at the European Ombudsman. ${ }^{56}$ We recognise the importance of each of the available options discussed by Schmalenbach. For our purpose, however, parliamentary and civil society scrutiny appears to be one of the most important tools, given that there is already considerable interest among some EU Parliamentarians on what is currently happening in Eritrea. To that we turn our focus in the next section.

\section{G. Effective Parliamentary and Civil Society Scrutiny as a Remedy ${ }^{57}$}

There is no doubt that the EU needs to revise the terms and conditions of its external relations with Eritrea. The question is how should this be done? The EU has not clearly articulated the objectives of its development cooperation with Eritrea as its engagement fails to fulfil essential criteria of respect for human rights, democratic accountability and the rule of law in Eritrea, as stipulated by the main EU treaties and the Cotonou Agreement. The EU's continued and unrealistic engagement with Eritrea is seen as the only factor legitimising a government whose sources of legitimacy have been severely eroded internally and externally. One way of improving EU-Eritrea relations is through the strengthening of European Parliamentary scrutiny

55 Schmalenbach, note 14, pp. 82-83. In support of her argument, Schmalenbach also cites Philip Dann, Accountability in Development Aid Law: The World Bank, UNDP and Emerging Structures of Transnational Oversight, Archiv des Völkerrechts, 44 (2006), pp. 388-389.

56 See generally Schmalenbach, note 14.

57 Some paragraphs of this section draw on Mirjam van Reisen, Strengthening European Parliamentary Scrutiny of EU Development Cooperation in Geographic Strategy Papers, Multi-Annual Indicative Programmes and Strategy Papers', EEPA Briefing Paper, 16 November 2010. 
of EU-Eritrea development cooperation. The authors align this recommendation with ongoing efforts at the EU level to make the European Parliament a meaningful actor in the approval of the EU's CSPs. If there are significant doubts as to whether the CSP of Eritrea is within the legal parameters set by the EU legal provisions, the European Parliament has the right and obligation to check with verification by the European Court of Justice (Article 218 of TFEU). Earlier cases of doubt about whether cooperation programmes remained within established criteria and objectives have been brought by the European Parliament to the European Court of Justice for a ruling. ${ }^{58}$

The Lisbon Treaty has provided the European Parliament with new and additional powers relating to powers of assent over agreements with third countries and the multi annual policies and the resources allocated to support these, as agreed with third countries. The European Parliament should utilise these powers to ensure the European Commission act accountably within the Treaty obligations and adapt its cooperation with Eritrea accordingly. In addition, the European Parliament has an obligation to assess whether or not spending by the European Commission is within the law. This process of discharge takes place on an annual basis. The European Court of Auditors provides technical support to help the European Parliament in its process of discharge and questions raised as to the legality of spending under the EU cooperation programme. As a result, EU-Eritrea cooperation could be subject to a more detailed opinion by the European Court of Auditors.

Thus far, the European Parliament has been feeble in terms of its political weight and ability to challenge the European Commission's modus operandi for development cooperation and to hold the Commission accountable for its core principles and objectives. The authors believe that it is imperative for the European Parliament to have real political scrutiny over development cooperation with the developing world, particularly in countries such as Eritrea, which are stretched to the level of breaking point due to an extremely closed political culture and anti-democratic system of governance.

In addition to the above, the following are also important steps for an improved EU-Eritrea development cooperation. Article 2 of Annex IV of the Cotonou Agreement stipulates that development cooperation programmes are to be designed by the concerned ACP State and the EU "following consultations with a wide range of actors in the development process". In the case of Eritrea, the phrase "a wide range of actors" should be understood to include Eritrean diaspora communities. Eritrea has one of the largest diaspora communities proportional to its population (anecdotal figures put the Eritrean diaspora at more than 1.5 million out of a total population of 4 million). Thus far, there has not been any meaningful involvement of these actors in the negotiation of the CSP and NIP for Eritrea, particularly in the negotiation process, which was finalised on 2 September 2009. This is despite persistent calls from such groups of excluded actors, one of which is the Eritrean Reference Group working under the auspices

58 See, for example, European Court of Justice, Commission v Council, C-91/05, Judgement of 20 May 2008; European Court of Justice, Parliament v Commission, C-403/05, Judgement of 23 October 2007. 
of Europe External Policy Advisors (EEPA) ${ }^{59}$ It is incumbent upon the EU to devise a strategy that ensures proper representation of, and consultation with, important segments of the Eritrean diaspora. There are hopes that the shortcomings identified in this paper may be addressed in operational review processes that take place in the future. Article 7 of the bilateral agreement signed by Eritrea and the EU on 2 September 2009 stipulates that the two parties shall undertake an annual, mid-term and end of term operational review of the instruments governing the development cooperation in light of prevailing needs and performance. At the time of writing, two years have already passed since the signing of the bilateral agreement and the authors are unaware of any annual operational review taking place with the input of non-state actors. In addition, the difference between a yearly and mid-tem review is not clear, because the bilateral agreement also says that the mid-term review is to be undertaken in 2010 , just a year after the agreement was signed. The Cotonou Agreement includes mechanisms for the "regular assessment of the developments concerning the respect for human rights, democratic principles, the rule of law and good governance." The EU should involve Eritrean diaspora communities in any regular assessments of Eritrea. If the yearly and mid-term reviews of the CSP and NIP have not yet been conducted, the authors are hopeful that the EU will take into consideration the recommendations made in this paper when these operational reviews are undertaken. Indeed, what was overlooked in the initial negotiation phase of the 2009-2013 CSP and NIP should not be overlooked in the forthcoming operational reviews. If political dialogue between the EU and the Government of Eritrea is not meaningful, the European Commission needs to take recourse to the non-execution clause as provided for in the Cotonou Agreement.

\section{H. Concluding Remarks}

The EU is one of the leading global actors in development cooperation. As much as it has become a major player in the eradication of poverty and the attainment of sustainable economic development, the EU's engagement with Eritrea is seriously undermining its obligations under the Treaty of Lisbon, the Treaty of the European Union, the EU Regulations on DCI, the European Consensus and Development and the Cotonou Agreement. The authors suggest that the EU's development cooperation in Eritrea should be revised in line with obligations under the EU Treaty and sub-Treaty legislation. The political situation in Eritrea is replete with factors that lead to alarming levels of individual and collective victimisation, which are a serious threat to human security. As a result, the legitimacy of the Eritrean Government has been severely eroded internally and externally. There is a large amount of information about the poor track record of the Eritrean Government in relation to respect for human rights, democratic accountability and the rule of law. Despite this, the EU continues to send large amounts of taxpayers' money to Eritrea, a country ruled by a government that the lacks ad-

59 See, for example, the following calls made by some of the members of the Eritrean Reference Group at EEPA and the Director of EEPA at different times: Daniel R. Mekonnen, Controversies on EU's Country Strategy Paper for Eritrea, New Europe, 1 March 2009; van Reisen, note 45. 
ministrative, legislative and institutional provisions necessary for the effective monitoring and evaluation of development cooperation. Despite the increased levels of development cooperation by the EU, Eritrea has become an isolated nation that always makes it to the top of the list of human rights violators. This small country of 4 million inhabitants has become one of the leading refugee producing countries in the world. Can the EU, through its development cooperation, contribute to a restoration of respect for human rights, the rule of law and democratic accountability in Eritrea? In the last decade, Eritrea regressed rather than progressed in terms of its commitment to respect for human rights, democratic accountability and the rule of law, and there is no evidence that the EU has been able to support actions that create a more conducive environment through its cooperation with this country. The EU's direct support to the Government of Eritrea, by extension, allows human rights violations and the dictatorship to continue. This is reinforced by the silence around these issues on the part of the EU. The EU needs to strengthen positive aid measures to help refugees and support democratic organisations in the Eritrean diaspora. Eritrea has put the EU's foreign policy on development cooperation to a cardinal test. It is evident that the continued flow of large amounts of funds to Eritrea in an unaccountable fashion is an affront to European taxpayers, particularly in the context of the country's alarming record of human rights violations, including the prolonged detention without trial of thousands of political prisoners, such as Swedish journalist Dawit Isaak. There is an urgent need for the EU to assess its development cooperation in Eritrea in light of its treaty obligations emanating from the Treaty of Lisbon, the Treaty of the European Union, the EU Regulations on DCI, the European Consensus and Development and the Cotonou Agreement.

At a time when Eritrea has been hit by stringent UN Security Council sanctions, the EU needs to revise its relations with Eritrea so as to save itself from contradicting its commitment to respect for the principles of the UN Charter and international law, and to ensure that it fulfils its international social responsibility and treaty obligations. In light of the current debate, strengthening European Parliamentary scrutiny over development cooperation is one of the most effective remedies. In the upcoming operational reviews, the EU is expected to revise its strategy and grasp the opportunity missed during the initial phase of its engagement in the 10th EDF. The involvement of important stakeholders, such as Eritrean diaspora actors, in the negotiation of the terms and conditions of development cooperation is another vital factor. The authors also believe that the EU should invoke the non-execution clause in the Cotonou Agreement if the Eritrean Government does not take concrete steps to meet its commitment in relation to respect for human rights, democratic accountability and the rule of law. Questions over the legality of spending under the EU development cooperation programme with Eritrea should be subject to a more detailed opinion by the European Court of Auditors during the annual process of discharge by the European Parliament. In the event that all such options prove ineffective, it would be advisable for the European Parliament to obtain the opinion of the European Court of Justice on the viability of the bilateral agreement signed between Eritrea and the EU on 2 September 2009, as stipulated in Article 218 of the Treaty of the European Union. 